\title{
Historical-and-economic aspects of production of swine breeding by agricultural commodity producers of Ukraine in pre-soviet period
}

\author{
M. Ibatullin, \\ Candidate of Sciences (Economics) \\ National University of Life and Environmental Sciences of Ukraine
}

The purpose. Development of theoretical rules and practical references on overgrowth of production of swine breeding by agricultural commodity producers on the basis of generalization of historical experience of development of the branch. Methods. Dialectic method of scientific knowledge, analysis and synthesis; systemic generalization. Results. Historical-and-economic assessment of development of swine breeding in Ukraine is realized. It is fixed that production of swine breeding was the original indicator of consistency and well-being of life of rural families. Principal cause of growing of pigs of larding type was demand of foreign consumers, first of all shipbuilders of England where lard was used only for the engineering purposes. It stimulated to selection of larding breeds of pigs. Principal cause of development of industrial swine breeding was the developed food reserve. According to it division into districts of growing pigs was carried out. The highest level of density of pigs was observed in districts where the factories of the industry were, in particular distilling plants. Conclusions. During the long historical period production of swine breeding was traditional branch of agriculture of Ukraine. Use of practical approaches acquired during economic activities to growing and marketing pigs is of utmost importance nowadays. Their well-timed adaptation stimulated revitalization of swine breeding and ensured high level of competitive strength as in the inner and outer markets.

Key words: swine breeding, production, consumption, collective farms, personal agriculture.

Formulation of the problem. Many years of observation indicate that the problem of providing the population and the food industry with meat is almost impossible to solve without the intensive development of all branches of livestock and, in particular, pig farming.

Despite the fact that pork for religious and other reasons does not consume not only individual nations, but also some regions of the world, over 100 million tons, or about $40 \%$, is in the total production of meat. The priority of the development of this industry is given exclusively due to such important biological and economic features of pigs as omniveness, multiplicity, economical use of feed, the suitability of slaughter products for various culinary products of everyday use and long-term storage.

Research methods. Dialectical method of scientific knowledge, analysis and synthesis, system generalization.

The purpose of the research is to develop theoretical principles and practical recommendations for increasing the production of pig production with agricultural producers on the basis of the generalization of the historical experience of the development of this branch of livestock breeding.

Presentation of the main research material. In the middle of the seventeenth century, a French engineer who was in service in the Commonwealth and left one of the most famous and interesting descriptions of Ukraine in the Cossack era - Guillaume Levasar de Boplan, describing, among other things, the diversity of Ukrainian cuisine, noted the importance of lard in the Ukrainian diet [1].

So naturally, pork has long been cultivated in Ukrainian economy. At the same time, researchers note that the occupation of pigs was a pivotal indicator of the prosperity and well-being of peasant families, since the very poor were not able to deal with them [2]. As an exception, the latter was possible only on a completely "upright" stern, that is, "on the margin". In Ukraine, this happened only in ancient times, in the absence of a land use shortage (XIV-XV centuries), or in the conditions of a large number of unoccupied lands in the Cossack region, that is, in areas adjacent to the "no-man" steppe, or so called "Wild Field" (in the XVII - early XVIII century). The most ancient documentary information on the development of pig breeding in Ukraine refers to the XVIII century. It was at that time that European consumer demand for pork fat appeared. This is due to the rapid construction of the navy in England, which, remaining still wooden, needed a huge amount of fat as a lubricant for "emanating" the wooden bottoms of vessels, as well as lubricating all the mobile wooden parts of ships. Thus, by this time, the first breeding successes in the derivation of pig breeds also apply. In particular, Berkshire and Yorkshire breeds of pigs were harvested in England [3]. 
Commodity demand contributed to the production of the proposal. It was in the XVIII century. (after the Cossack-peasant anti-Polish wars of the second half of the XVII century), the Polish Right-bank was quickly reborn by the Philharmonic (that is, organized for the production of commodity products) economy of the Polish magnates. Ukrainian historian Valentina Markina devoted to the study of the problem of magnate nomads in a special study and on documentary materials showed, among other things, the significance of pig production in the production of magnate filvers, in correlation with other commodity products. Thus, for example, in the places of S. Pototsky, on the 12-year-olds Tulchynchyna and Braylivshchyna, as of 1783 there were 358 oxen, 204 cows, and 239 heads. young and 72 goals. outgrowing cattle (ie, on pastures), hence, in total - 914 goals; and in addition - 908 sheep and 1408 pigs [4]. As you can see, the share of pig production in the total number of commodity creatures is more than significant. According to the estimates of $\mathrm{V}$. Markina, on average one flour warrior came from plowshares - 26, dairy cows - 11, pigs - from 50 to 125 [4]. An even bigger number of pigs in Czartoriyskiy's drinkers at Mezhybozhchin - 1900 head. as of 1742. And as for all Podillya filwarks of these magnates, the following dynamics of figures are given: in 1766 - 4872 goals. pigs in $1773-3943$, in 1775 4870, in 1784 - 6636, in 1787 - 7032 heads. pigs [3].

At the same time, documents show that in a number of fishermen, such as in Zhevushi in the Novokostyantinovsky and Kolodyazhnyi farms in Volhynia, a significant amount of livestock was produced (the documents distinguish the number of oxen, bulls, dairy and feral cows, young animals), as well as horses and sheep, but - pigs there is no mention [4]. Consequently, we can conclude that pig production occupied an extremely important position in the production of fishery products, but only in the presence of a suitable feed base, in particular, and most of all - distillery waste [4]. In each such filvik, pigs were fed for their own domestic needs, as well as for sale.

V. Markina gives a valuable documentary source, dated 1802, concerning the organization of commercial pig production in the Uman estates of S. Pototsky. It says, however, that "fattening pigs on vnets should be turned into" net income ", for the purpose of half a year to feed the pigs by bragg, and then take their second party, at the expense of issuing for each pig of 3 Cossacks (that is, about 10 pounds) of "litter" or "bright" grain. It is extremely important to increase the number of pigs in filvarkaki, and buy them to arrange so that in the year bought at least 1500 pigs for fattening in the main vineyards, and another 1500 - for the needs of the fisherman "[4].

A similar dependence of pig barley from the feed base was maintained in the nineteenth century. In particular, Ivan Gurzhy, referring to the documents of the office of the governor of Chernihiv, states that the landowners of Chernigov region fed their purchased pigs on their hosts, and then sold lard and meat in close and distant markets [5]. As for peasant farms, they are in the first half of the nineteenth century. predominantly kept intact and when residents of villages close to the city sold milk, meat, fat, etc., this was often a forced demand because of the need to obtain money for payment of taxes [5].

As for the market demand for pork as of the middle of the nineteenth century, the volumes of sales of these products at fairs are quite revealing in comparison with other products. So, only from the districts of the Kharkiv province on the city's Kharkiv fairs during the 50 years of the year, they sold various commodities by about 2.5 million rubles, including fat, 70 thousand poods for 165 thousand rubles, meat 100 thousand pounds for 100, flour 400 thousand pounds for 350 thousand rubles, and also honey, wax, sugar, wool, leather, cloth, etc. . [5]. In addition to the Kharkiv fairs (which for 4 years were 4 - Khreshchanskiy, Trinity, Uspensky and Pokrovsky), there were also bazaars, where the merchants also bought from the peasants fat, meat, honey, wax, cattle for sending to Petersburg and twice a week. Moscow [5].

It is interesting to draw attention to the statistics of consumed products in order to determine the share of pig production in the diet of Ukrainians of the nineteenth century. According to the documentary evidence of the office of the governor of Chernihiv in 1836, residents of the cities of Chernigiv oblast consumed 32,200 bags of rye flour; 6,500 bags of wheat flour; 16,200 quarters of different cereals; 46 thousand poods of beef; 29 lamb 1,25 - veal; 8 - pork and over 5 thousand pounds of corn [5].

Such statistics have remained for the city of Kiev as of 1844 . The city's population during the year was buying wheat and rye flour 213 thousand pounds; different cereals 46.5 thousand poods; potatoes and cabbage - 24,5 thousand carts; different green 28 thousand cart; oil is 15 thousand pounds; meat - 80; bacon - 46; oil 20 thousand pounds; milk - 82 thousand jugs; calves 7 thousand heads .; 3.5 thousand heads of pigs .; chickens and chickens 125 thousand; ducks and turkeys 90 thousand goals .; salts - 100 thousand pounds; fresh, salty and dried fish - 43; honey - 16 thousand pounds [5].

As we can see, with a fairly wide variety of ration of city dwellers, pork did not occupy leading positions, although its share, it must be admitted, was not small. Consumption of fat at the level of consumption of the same amount of all kinds of cereals is rather indicative. During the second half of the nineteenth century. Ukraine was involved, as is known, in the global bread market. In order to increase the shaft of commodity 
grain, respectively, there was a growth of sown areas. This was due to the plowing of steppe virgin lands (the so-called "Wild Field"), as well as a significant reduction in pastures (the latter led to a decrease in sheep breeding), but at the same time there was a tendency to increase the number of domestic livestock, that is, the breeding of pigs that can be treated without grazing. The latter was also promoted by the intensive development of sugar cultivation, which grew especially in the second half of the nineteenth century. in the Ukrainian Right Bank.

Hence, the number of pigs, according to Mikhail Slabchenko, from 1851 to 1871 in the Right-Bank Ukraine grew by a third, and in Steppe Ukraine almost doubled [6]. Valentyna Kryzhanivska gives concrete figures for pigs in the Right Bank of Ukraine during the given period. According to her data, at the beginning of the 60 s of the nineteenth century. it amounted to almost 1.15 million, and in 20 years, until the beginning of the 80 's of the nineteenth century. increased by reaching 1.44 million head, that is, almost $30 \%$ [6]. At the same time, the researcher claims that in the second half of the nineteenth century, only wealthy families could afford to use pork for the entire "meat-eaters", that is, from Christmas to Oily, and even more so after Easter. Most Ukrainian peasants could eat it only on holidays of Christmas and Easter [6].

The General Imperial Russian statistics showed that in the given period in Ukraine (and in particular in the Podillya and Volyn provinces), as well as in Chernigov region (along with the three provinces of Belarus), the highest percentage of pig breeding was for the entire Russian Empire. Here, the share of pigs was more than $20 \%$ of the total amount of 4 species of peasant livestock (ie, horses, cattle, sheep and pigs). Moreover, if the total empire per 100 people in the population accounted for about 11 pigs, then in these provinces, this share was more than 20 goals. [7]. At the same time, in typical Russian provinces (such as Moscow, Yaroslavl, Vladimir, etc.) statistics accounted for less than 2 heads of pigs per 100 population of the population [7].

At the same time, the researcher states that the population growth in the Russian Empire surpassed the average increase in the pig breeding industry. Thus, in 1857, there were 15 goals per 100 souls in the population. pigs; in 1870 there were 13; in 1883 - 12; and in 1888 this number was reduced to 11 goals. [7].

\section{Conclusions}

During the long historical period, the production of pig products was a traditional branch of agriculture in Ukraine. The use of practical approaches to keeping and marketing pigs acquired in the process of economic activity is also relevant today. Particular attention deserves the development of sales infrastructure, in particular, the functioning of markets for live livestock and boys, as well as regulatory and legislative support for their activities. Their timely adaptation stimulated the revival of pig breeding, which provided a high level of competitiveness both in the domestic and foreign markets.

\section{Bibliography}

1. Boyko AV Our fat: history, ways of pickle, jokes / AV. Boo - K., 2007. 64 p.

2. Guillaume Levasar de Boplan. Description of Ukraine.Prosper Merimee. Ukrainian Cossacks. Bogdan Khmelnitsky / Guillaume Levasar de Boplan: trans. from French, Notes and Preface of Yaremi Kravets. -Lviv: Kamenyar, 1990. - $301 \mathrm{p}$.

3. Development of commodity production and trade in Ukraine (from the end of XIII century until 1861) / I.O. Gurzhi -K., 1862. - 197 p.

4. The history of the Ukrainian peasantry. Essays in 2 volumes / AV. Blanutsa, KP Bunyatyan, D.P. Vashchuk and others. -K .: Science. thought, 2006. - T. 1. - $631 \mathrm{p}$.

5. Markina V.A. The magnate estate of the Right Bank of Ukraine in the second half of the XVIII century. (socio-economic development) / VA Markina -K: Izvestiya Kiev. Un-te, 1961. - 236 pp.

6. Slabchenko M.E. Materials for the economic and social history of Ukraine of the XIX century. In 2 volumes / M.E. Slabchenko. - K .: State. kind of Ukraine, 1927. -T. 2. - 278 pp.

7. Fortunatov A. Statistics of European Russia / A. Fortunates. - Moscow, 1893. - 247 pp.

8. Review of Russia's foreign trade on European and Asian borders for 1872. - St. Petersburg, 1873. - P. 206,250 .

9. Galsky K. E. Trade and Customs in Ukraine (XVI-XVIII centuries) / K.E. Gaulish. - K .: Panorama, 2010. $400 \mathrm{p}$.

10. Morozov O.V. Customs ideology of the Russian Empire and capitalization in the Ukrainian provinces in the first half of the nineteenth century. / O.V. Morozov // Grani. - 2010. - No. 4. - P. 3 - 8. 